\title{
LASER WELDING OF COMMERCIAL ARC SLAG REMELTED TITANIUM VT1-0 HARDENED BY NITROGEN
}

\author{
V.D. SHELYAGIN, V.Ya. SAENKO, A.A. POLISHKO, V.A. RYABININ, A.V. BERNATSKY, \\ S.N. STEPANYUK and I.N. KLOCHKOV \\ E.O. Paton Electric Welding Institute, NASU
}

11 Bozhenko Str., 03680, Kiev, Ukraine. E-mail: office@paton.kiev.ua

\begin{abstract}
The possibility of producing the full-strength butt joint of sheet rolled titanium VT1-0 of $12 \mathrm{~mm}$ thickness, preliminary hardened by nitrogen $(0.098 \mathrm{wt} . \%)$ from the gas phase in the process of arc slag remelting, using laser welding was shown. In the course of experimental investigations double-sided welding of butt joints applying Nd:YAG-laser radiation was performed. The results of macro- and microinvestigations, measurements of distribution of microhardness $H V$, mechanical properties in testing on static tension and impact bending proved a high quality of welded joints. The homogeneity of the structure, absence of cracks, pores and other defects evidence of the challenging development of technology of laser welding of commercial titanium VT1-0 hardened by nitrogen (up to 0.1 wt.\%) in ASR. 9 Ref., 4 Tables, 11 Figures.
\end{abstract}

Keywords: laser welding, commercial titanium, hardening by nitrogen from gas phase, weldability, butt joint, micro-, macrostructure, microhardness, mechanical properties

Widening of production and application of titanium and its alloys in different branches of engineering caused, in the first turn, by their increased specific strength (relation of tensile strength to density). High corrosion resistance of titanium under the atmospheric conditions, sea water and a number of high-aggressive environments predetermines its efficient use for manufacture of welded structures operating in the most severe conditions. The volumes of industrial use of these structures depend greatly on modernization of technological processes of their manufacture and, first of all, welding. The main problems of titanium welding include serious difficulties caused by its high chemical activity at elevated temperatures. In welding a reliable protection of weld pool from surrounding environment is required to eliminate interaction with gases of atmosphere, otherwise the welded joints loose their ductility, the defects are formed in welds, in particular, pores. To provide a good weldability of titanium and its alloys the content of harmful impurities, such as gases (oxygen, nitrogen, hydrogen) and carbon is restricted. Thus, commercial titanium VT1-0 contains, wt. $\%$ : $0.12 \mathrm{O}_{2}, 0.04 \mathrm{~N}_{2}, 0.01 \mathrm{H}_{2}, 0.07 \mathrm{C}$ [1].

As a result of complex of investigations carried out at the E.O. Paton Electric Welding Institute
[2-4] the possibility of more than 1.5 times increase of level of strength characteristics of commercial titanium of VT1-0 grade (GOST 2375579) was established by its alloying with nitrogen up to $0.1 \mathrm{wt} . \%$ from gas phase in the process of melting ingots using method of arc slag remelting (ASR). Moreover, in spite of the real content of nitrogen (0.069 and 0.098 wt.\%), in hardened titanium VT1-0 of 14-152 and 5-35 mm thickness in ASR, the values of elongation and reduction in area are at the high level $-\delta=14-27 \%$ and $\psi=32.5-47 \%$.

One of the main tasks of investigation of metallurgical quality and technological properties of sheet rolled titanium VT1-0, hardened by nitrogen, as a new structural material is its weldability.

Earlier [5], the efficiency of application of electron beam welding to produce welded joints of full-strength with base metal (BM) of sheet commercial titanium VT1-0 of $35 \mathrm{~mm}$ thickness, hardened by nitrogen up to $0.1 \%$ from gas phase in ASR process, was shown. Metallographic investigations proved the production of the quality welded joint without cracks, pores and other defects, in spite of the fact that the real content of nitrogen $(0.098 \%)$ in BM almost 2.5 times exceeds the admissible $(\leq 0.04 \%)$ content in VT1-0 titanium according to GOST 19807-74. Weld metal and BM are characterized by the homogeneous structure.

\footnotetext{
${ }^{*}$ In this work A.V. Siora and A.Yu. Tunik participated. 
New capabilities in the production of critical welded structures of titanium and its alloys are opened as a result of application of laser and hybrid laser-arc welding for this purpose [6, 7]. The important is also the fact that laser welding is one of the challenging methods allowing producing high-quality and long-life welded joints almost without residual deformations [8].

The aim of this work is the investigation of weldability of butt joints of sheet rolled titanium VT1-0 of up to $12 \mathrm{~mm}$ thickness, hardened by nitrogen $(0.098 \%)$ from gas phase in ASR, with evaluation of possibility of producing welded joint of full strength using laser radiation.

To achieve the put aim, the experiments on laser welding of double-sided butt joints were carried out.

The chemical composition of sheet rolled titanium VT1-0 ASR $12 \mathrm{~mm}$ thick, used for welded specimens, is given in Table 1 , and its mechanical properties - in Table 2 .

The experiments were carried out in laboratory stand mounted on the base of three-coordinate manipulator «Lastochka-1» of the PWI production. For experiments ROFIN-SINAR Nd:YAG-laser DY044 (Germany) was used with radiation wave length $\lambda=1.06 \mu \mathrm{m}$. Laser radiation was transmitted along the optic fiber manufactured of quartz glass of $600 \mu \mathrm{m}$ diameter and $20 \mathrm{~m}$ length. From the optic fiber the laser radiation got to the collimator, where it was transformed by means of the optic elements system,

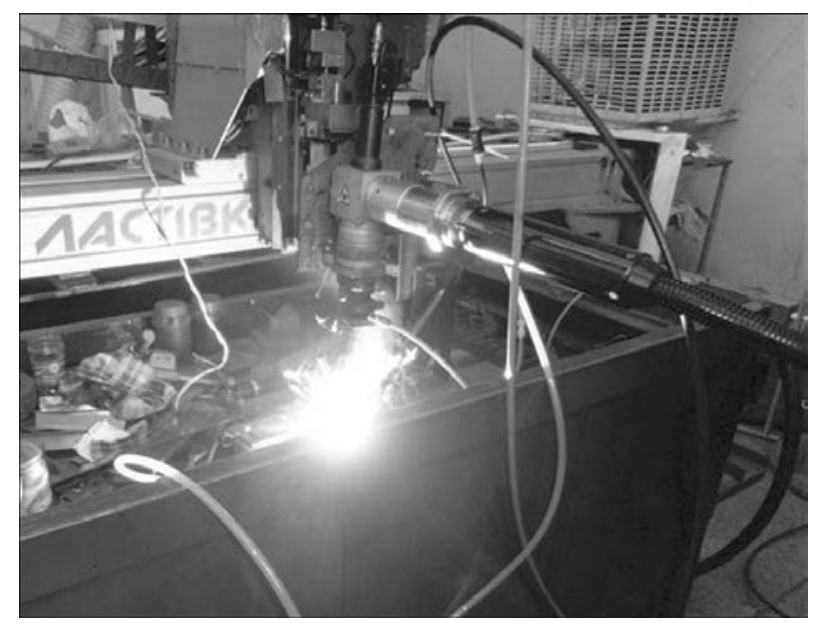

Figure 1. Process of laser welding of double-sided butt joint of sheet rolled titanium VT1-0 $12 \mathrm{~mm}$ thick, hardened by nitrogen (0.098 wt.\%) from gas phase in the ASR process

acquired the necessary geometric sizes and then got to the focusing quartz lens of $50 \mathrm{~mm}$ diameter with focus distance $F=300 \mathrm{~mm}$. The experiments were carried out according to the scheme given in work [6]. The specimens were fixed in the screw clamp, positioned on the object sample table, and laser head was fastened on the movable carriage of manipulator as it is shown in Figure 1. The welding was performed in the atmosphere of active $\left(\mathrm{N}_{2}\right)$ and inert $(\mathrm{Ar}, \mathrm{He})$ gases. Technological modes of welding of plates of alloy VT1-0 ASR $12 \mathrm{~mm}$ thick, hardened by nitrogen $(0.098 \%)$, are given in Table 3 .

The produced welded joints were subjected to macro- and microstructure examinations and also

Table 1. Comparison of chemical composition (wt.\%) of sheet rolled titanium of VT1-0 grade and VT1-0 ASR

\begin{tabular}{|c|c|c|c|c|c|c|}
\hline Material & $\mathrm{Al}$ & $\mathrm{Fe}$ & $\mathrm{C}$ & {$[\mathrm{N}]$} & [O] & {$[\mathrm{H}]$} \\
\hline VT1-0 ASR & 0.23 & 0.09 & 0.02 & 0.098 & 0.09 & 0.002 \\
\hline VT1-0 (GOST 19807-74) & $\leq 0.30$ & $\leq 0.30$ & $\leq 0.07$ & $\leq 0.04$ & $\leq 0.12$ & $\leq 0.01$ \\
\hline
\end{tabular}

Table 2. Mechanical properties of sheet rolled titanium VT1-0 and VT1-0 ASR 12 mm thick

\begin{tabular}{|c|c|c|c|c|c|}
\hline Material & $\sigma_{y}, \mathrm{MPa}$ & $\sigma_{\mathrm{t}}, \mathrm{MPa}$ & $\delta, \%$ & $\psi, \%$ & $K C U_{+20}, \mathrm{~J} / \mathrm{cm}^{2}$ \\
\hline VT1-0 ASR & 625 & 705 & 23 & 40.5 & 61 \\
\hline VT1-0 (GOST 23755-79) & - & $375-570$ & $10-13$ & $24-27$ & - \\
\hline
\end{tabular}

Table 3. Technological modes* of laser welding of plates of commercial titanium VT1-0 ASR hardened by nitrogen (0.098 wt.\%)

\begin{tabular}{|c|c|c|}
\hline $\begin{array}{l}\text { Number of } \\
\text { specimen }\end{array}$ & Size of specimen, mm & Gas atmosphere (gas consumption) \\
\hline 1 & $198 \times 194 \times 12$ & $\begin{array}{c}\text { He }- \text { weld pool }(201 / \mathrm{min}), \mathrm{Ar}-\text { tail side of pool }(141 / \mathrm{min}) \text {, } \\
\text { Ar }- \text { back side of weld }(101 / \mathrm{min})\end{array}$ \\
\hline 2 & $207 \times 197 \times 12$ & $\begin{array}{c}\mathrm{He}-\text { weld pool }(20 \mathrm{l} / \mathrm{min}), \mathrm{N}_{2}-\text { tail side of pool }(14 \mathrm{l} / \mathrm{min}) \text {, } \\
\text { Ar }- \text { back side of weld }(10 \mathrm{l} / \mathrm{min})\end{array}$ \\
\hline
\end{tabular}




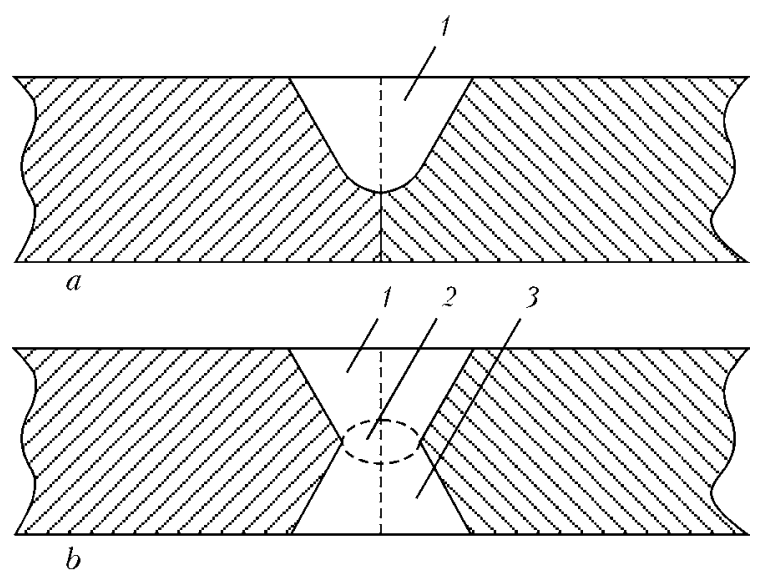

Figure 2. Schematic reproduction of stages of formation of double-sided butt joint in laser welding: $a$ - laser path on one side; $b$ - overlapping of laser path on the other side; 1 - weld $1 ; 2-$ weld root; 3 - weld 2

their mechanical characteristics during testing on static tension and impact bending in the aswelded state were determined.

The schematic reproduction of stages of formation of double-sided butt welds using laser welding is shown in Figure 2.

The appearance of welded plates and technological modes of laser welding on the both sides are given in Figures 3, 4 and in Table 3.
The double-sided butt welds on the both plates are characterized by a good formation, any surface defects in weld or HAZ metal were not detected.

Metallographic macro- and microexaminations (Figures 5 and 6) showed that the quality laser-welded butt joints without cracks, pores and other defects were produced according to both technological variants.

In specimen $1(\mathrm{He}+\mathrm{Ar}+\mathrm{Ar})$ the width of weld 1 amounts to $6.5 \mathrm{~mm}$, of weld 2 is $6.6 \mathrm{~mm}$, of weld root is $2.4 \mathrm{~mm}$ (see Figure 2), and width of HAZ is $0.3-0.5 \mathrm{~mm}$. In the whole volume of double-sided butt weld of specimen 1 the microstructure is composed of acicular martensite $\alpha$ phase. In weld 1 the needles are of different length $(10-15 \mu \mathrm{m})$. The size of grains at this area amounts to $250-450 \mu \mathrm{m}$, and the grains of $100-$ $150 \mu \mathrm{m}$ size can be found. The plate precipitates of $\alpha$-phase are observed, mainly along the boundaries of grains. In the weld root the size of grains amounts to $50-100 \mu \mathrm{m}$, they have innergranular acicular structure with the size of needles of $10 \mu \mathrm{m}$. Weld 2 has also acicular martensite structure. The size of grains is somewhat smaller - from 150 to $250 \mu \mathrm{m}$. In the HAZ metal the transition from finer grains in weld metal to
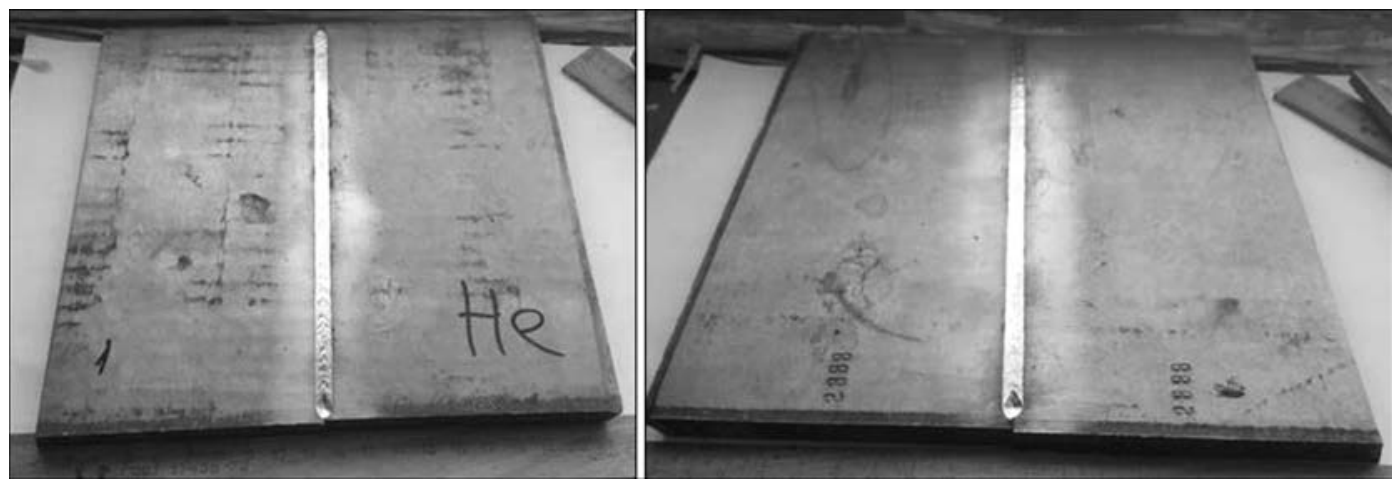

Figure 3. Appearance of plates of commercial titanium VT1-0 ASR $12 \mathrm{~mm}$ thick, hardened by nitrogen (0.098 wt.\%), welded in $\mathrm{He}+\mathrm{Ar}+\mathrm{Ar}$ atmosphere on both sides
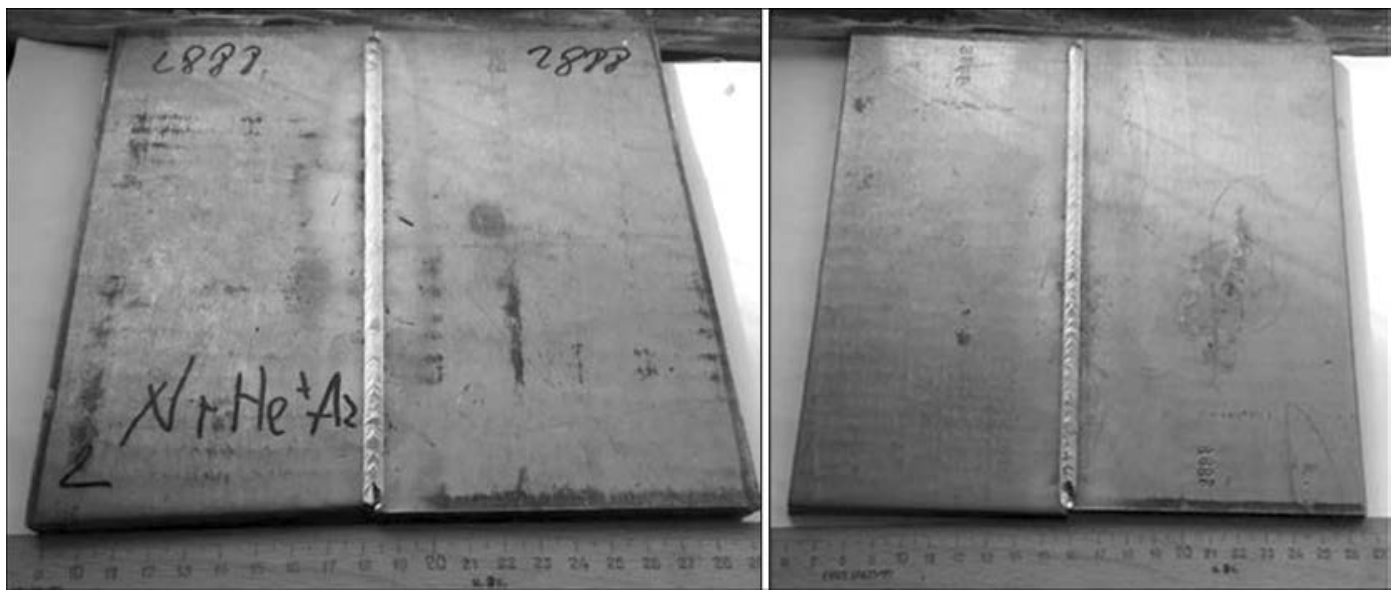

Figure 4. Appearance of plates of commercial titanium VT1-0 ASR $12 \mathrm{~mm}$ thick, hardened by nitrogen (0.098 wt.\%), welded in $\mathrm{He}+\mathrm{N}_{2}+\mathrm{Ar}$ atmosphere on both sides 


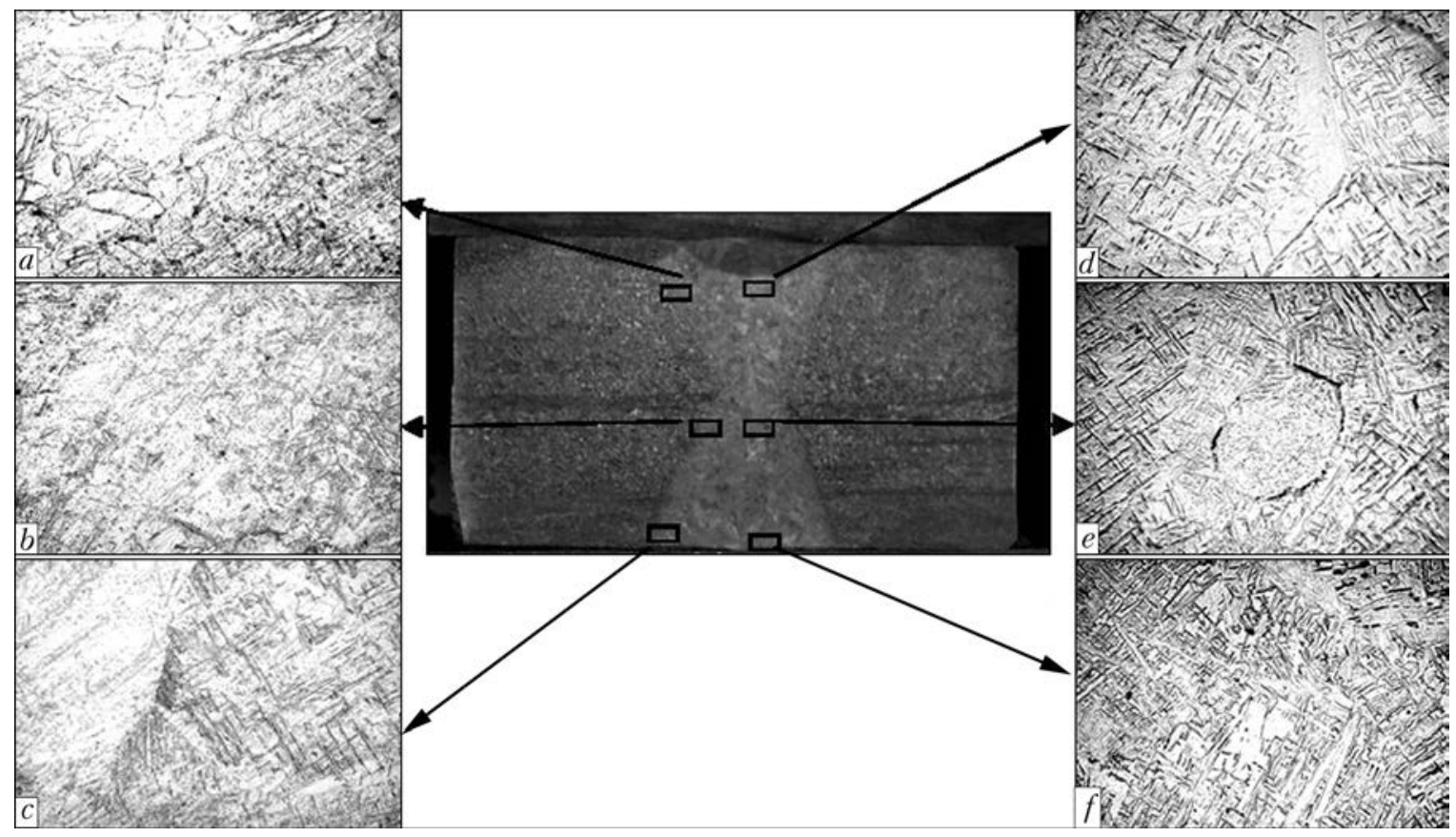

Figure 5. Macro- $(\times 2.5)$ and microstructure $(\times 500)$ of double-sided butt welded joint (specimen 1$)$ of commercial titanium VT1-0 ASR $12 \mathrm{~mm}$ thick, hardened by nitrogen (0.098 wt.\%), produced in $\mathrm{He}+\mathrm{Ar}+\mathrm{Ar}$ atmosphere: $a-\mathrm{HAZ}$ of weld $1 ; b$ - of weld root; $c$ - of weld $2 ; d$ - weld $1 ; e$ - weld root; $f$ - weld 2

coarser grains in $\mathrm{BM}$ is observed. In the HAZ no defects are observed (Figure 5).

In specimen $2\left(\mathrm{He}+\mathrm{N}_{2}+\mathrm{Ar}\right)$ the weld 1 width amounts to $6.8 \mathrm{~mm}$, weld $2-7.3 \mathrm{~mm}$, weld root $-2.6 \mathrm{~mm}$, and HAZ width amounts to $0.4-0.6 \mathrm{~mm}$. Throughout the whole volume of double-sided butt joint of specimen 2 the microstructure is composed of acicular martensite $\alpha$ phase. In weld 1 the needles are of different (5$15 \mu \mathrm{m})$ length. The size of grains at this area is from 150 to $250 \mu \mathrm{m}$. The plate precipitates of $\alpha$-phase are observed, mainly, along the boundaries of grains. In the overlapping zone the size of grains amounts to $40-100 \mu \mathrm{m}$, they have an innergranular acicular structure with the size of needles of $5-10 \mu \mathrm{m}$. The lower part of weld has also the acicular martensite structure. The size of grains is somewhat smaller - from 100 to $200 \mu \mathrm{m}$. In the HAZ metal the transition from finer grains in the weld metal to coarser grains in the $\mathrm{BM}$ is observed. In the HAZ metal no defects are observed (Figure 6).

Microhardness was measured on transverse microsections applying LECO hardness meter M400 at loading of $50 \mathrm{~g}$ with pitch of $100 \mu \mathrm{m}$ in different zones of welded joints: weld 1, weld

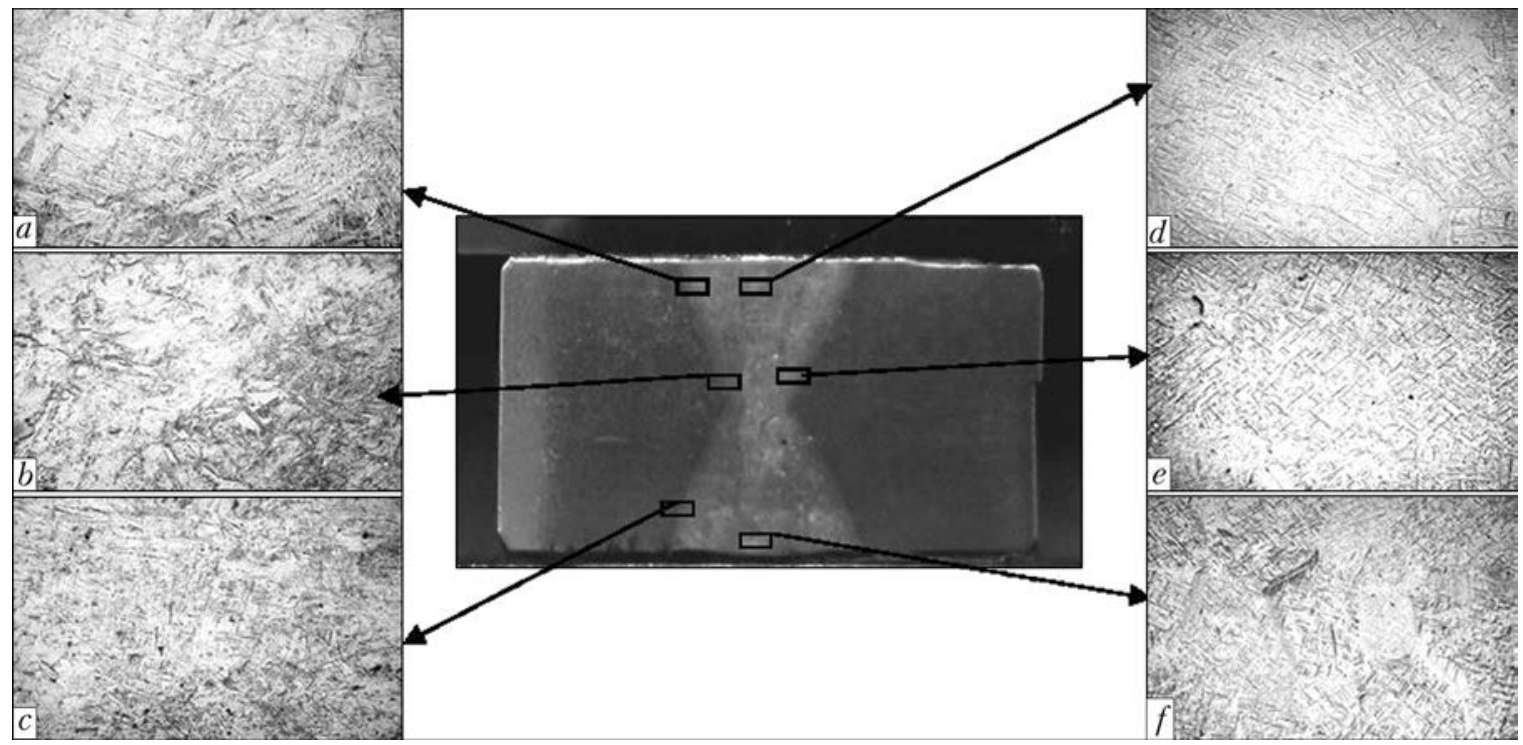

Figure 6. Macro- $(\times 2.5)$ and microstructure $(\times 500)$ of double-sided butt welded joint (specimen 2$)$ of commercial titanium VT1-0 ASR $12 \mathrm{~mm}$ thick, hardened by nitrogen (0.098 wt.\%), produced in $\mathrm{He}+\mathrm{N}_{2}+\operatorname{Ar}$ atmosphere $(a-f$ are the same as in Figure 6) 

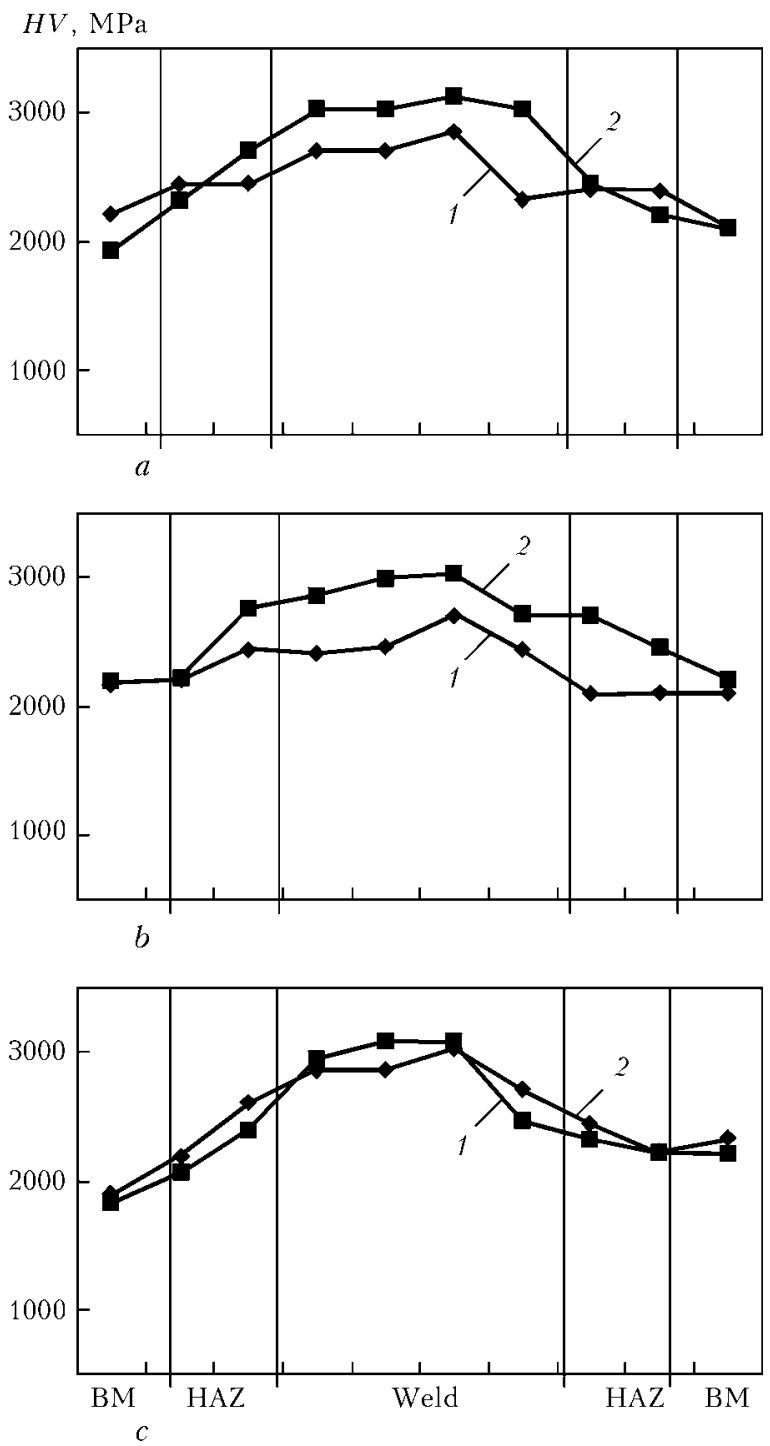

Figure 7. Distribution of microhardness along the height of welded joint, HAZ and BM of specimens of commercial titanium VT1-0 ASR $12 \mathrm{~mm}$ thick, hardened by nitrogen (0.098 wt.\%) in $\mathrm{He}+\mathrm{Ar}+\mathrm{Ar}$ (1) and $\mathrm{He}+\mathrm{N}_{2}+\mathrm{Ar}$ (2) atmosphere: $a$ - weld $1 ; b$ - weld root; $c$ - weld 2 (see Figure 2)

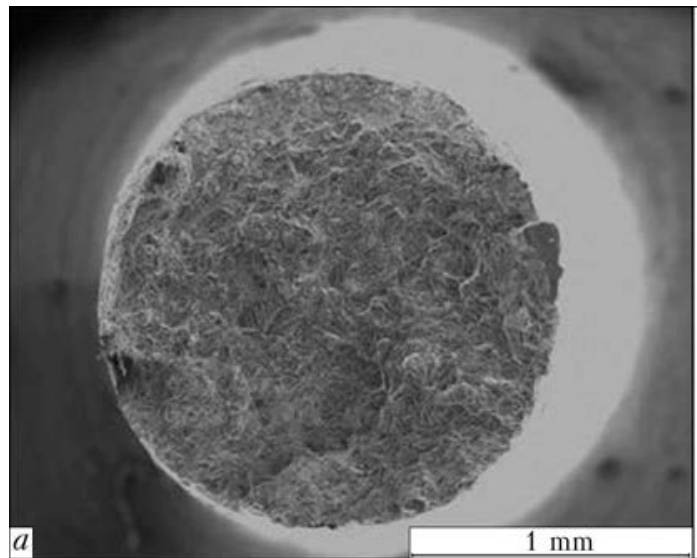

Table 4. Mechanical properties of double-sided butt welded joint of commercial titanium VT1-0 ASR $12 \mathrm{~mm}$ thick, hardened by nitrogen (0.098 wt.\%)

\begin{tabular}{|c|c|c|c|c|c|c||}
\hline \multirow{2}{*}{$\begin{array}{c}\text { Test } \\
\text { specimens }\end{array}$} & \multicolumn{5}{|c|}{ Mechanical properties } & \multirow{2}{*}{$\begin{array}{c}\text { Bending } \\
\text { angle, } \\
\text { deg. }\end{array}$} \\
\cline { 2 - 7 } & $\sigma_{\mathrm{t}}, \mathrm{MPa}$ & $\sigma_{\mathrm{y}}, \mathrm{MPa}$ & $\delta, \%$ & $\psi, \%$ & $\begin{array}{c}K C U, \\
\mathrm{~J} / \mathrm{cm}^{2}\end{array}$ & 45 \\
\hline 1 & 656 & 562 & 12 & 22 & 45 & 45 \\
\hline 2 & 677 & 613 & 15 & 37 & 43 & 63 \\
\hline
\end{tabular}

root and weld 2. The increase of values of microhardness from $\mathrm{BM}(H V$ 1830-2210 $\mathrm{MPa})$ to HAZ metal: in specimen $1(\mathrm{He}+\mathrm{Ar}+\mathrm{Ar})$ the average value is $H V 2372 \mathrm{MPa}$; in specimen 2 ( $\left.\mathrm{He}+\mathrm{N}_{2}+\mathrm{Ar}\right) H V 2373 \mathrm{MPa}$ is observed. In weld metal of specimen 1 the average value is $H V 2673$, in specimen 2 it is $2880 \mathrm{MPa}$. In general, the increase in level of microhardness in the weld metal of specimen 2 is observed as compared to the weld metal of specimen 1 at all the investigated levels as to the height. In HAZ metal the distribution of microhardness in the surface layers of weld in the whole volume of the produced joint in both specimens is almost equal. The mechanical tests of butt joints on static (short time) tension in the as-welded state (without heat treatment) were carried out according to the requirements of GOST 1497-84 and GOST 965184 . The tests were carried out in servohydraulic testing machine MTS 318.25 (USA) allowing the loading with maximum force of $250 \mathrm{kN}$ with error of up to \pm 0.5 . The results were processed using MTS software TestWorks 4. The accuracy of obtained results is $\pm 0.5 \%$, and according to GOST $1497-78$ it is up to $1 \%$.

The tests were carried out on the specimens with the middle notch by one shock of pneumatic pendulum hammer of 2130-KM-03 type with rated potential energy of pendulum of $300 \mathrm{~J}$ at

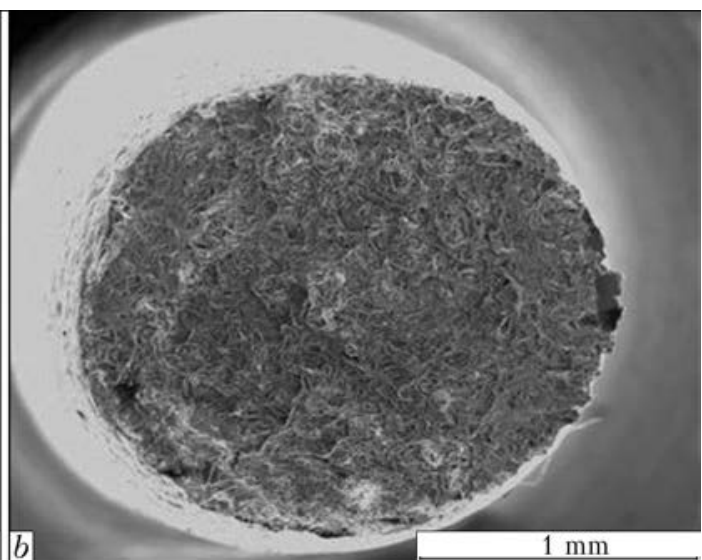

Figure 8. Macrofractograms of fracture surfaces after tests on static tension (here and in Figures 9-11 below: $a-$ specimen of welded joint $1 ; b-$ specimen of welded joint 2 of commercial titanium VT1-0 ASR 12 mm thick, hardened by nitrogen $(0.098$ wt.\%) 

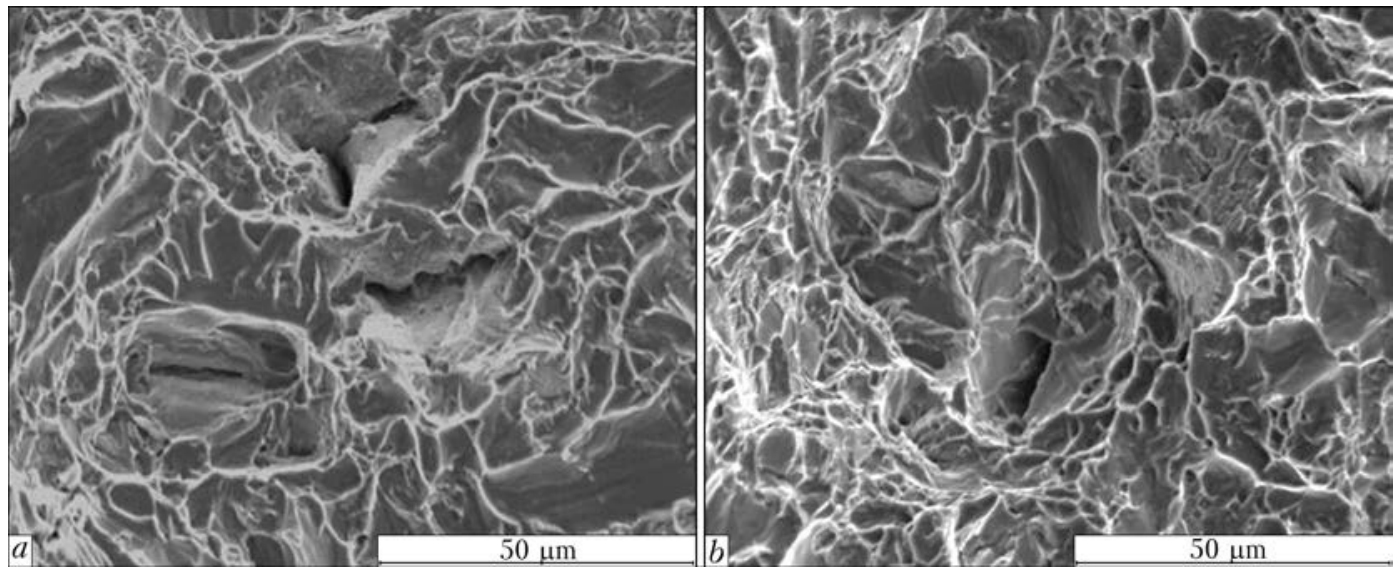

Figure 9. Fractograms of fracture surfaces after tests on static tension

the temperature of $20^{\circ} \mathrm{C}$. The results of mechanical tests are given in Table 4.

The fracture of specimens after tests on static (short time) tension in both cases was occurred along the BM. The notches of specimens for tests on impact bending are made along the weld. The angle of bending for laser weld of variant 1 is $45^{\circ}$, and for the weld of variant 2 is almost 1.5 times larger and equal to $63^{\circ}$ (see Table 4 ).

On macrofractograms of fracture surfaces after tests on static tension in both cases the plane fracture with small traces of shrinkage at the lateral surfaces of specimens is seen (Figure 8).
Fractograms of fracture surfaces after tests on static tension show pitting microrelief with projections. The pits of different sizes from 5-10 to 20-30 $\mu \mathrm{m}$ on the fracture surface of specimen 1 (Figure $9, a$ ), and from $2-5$ to $15-20 \mu \mathrm{m}$ on the fracture surface of specimen 2 (Figure 9, $b$ ) are seen. In both cases the areas of secondary cracking were observed.

Macrofractograms of fracture surfaces after tests on impact bending of specimens are fibrous, on the fracture surface of specimen 1 the projections were observed. The surface of specimen 2 is fibrous and plane (Figure 10).
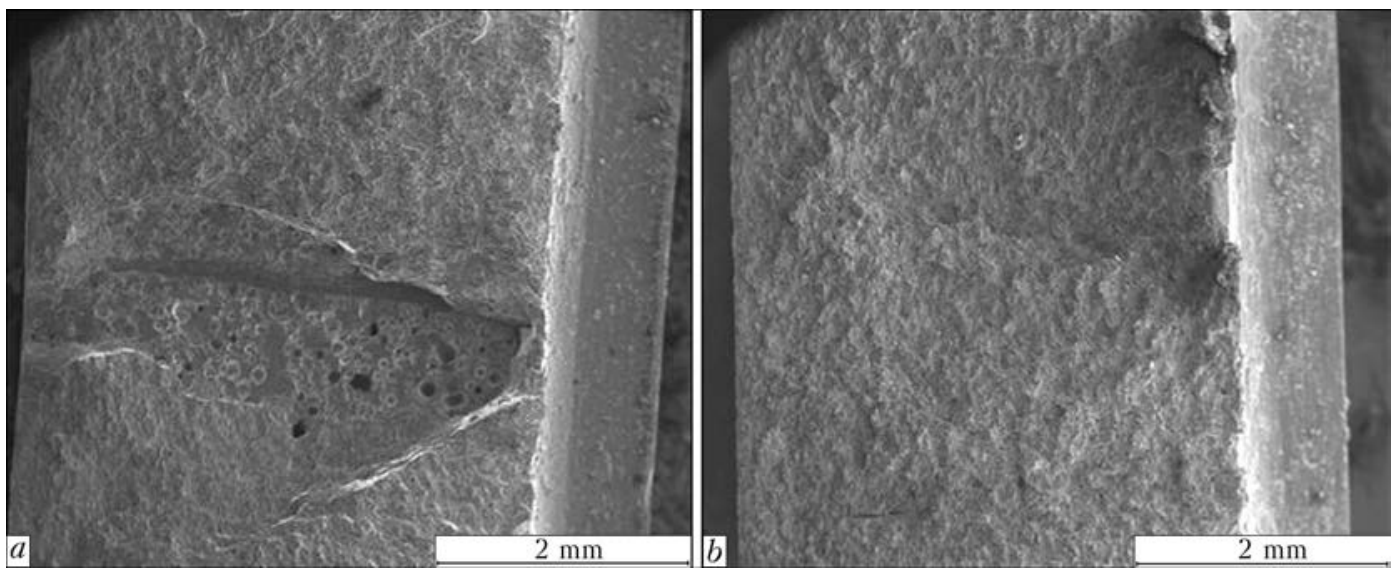

Figure 10. Macrofractograms of fracture surfaces after tests on impact bending
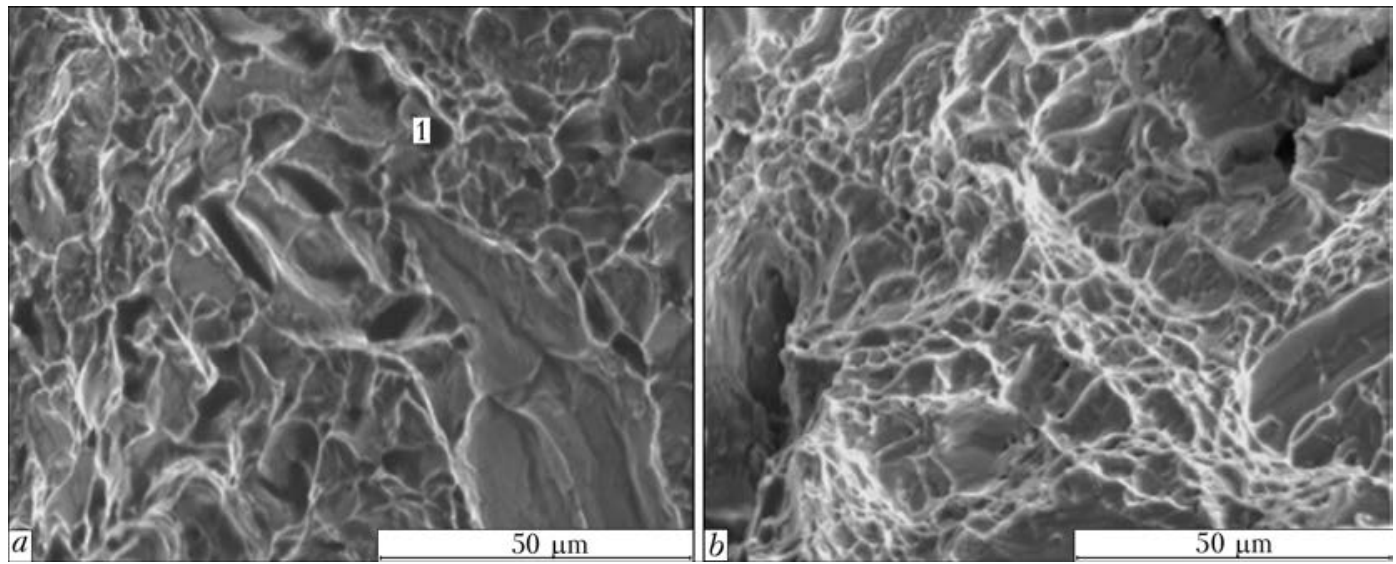

Figure 11. Fractograms of fracture surfaces after tests on impact bending 
During analysis of fractograms of fracture surfaces after tests on impact bending the deep pits with inclusions are observed being the centers of their origination. The mixed mechanism of fracture is observed, i.e. combination of secondary intergranular fracture, and in case 1 (Figure 11, a) there is a small number of pits of the size from $5-10$ to $15-20 \mu \mathrm{m}$ and in case 2 (Figure $11, b$ ) a large number of them of the size from $2-3$ to $5-15 \mu \mathrm{m}$.

In general, fractographic analysis showed the mixed mechanism of fracture: the combination of secondary intergranular fracture and signs of tough pitting character of fracture [9].

\section{Conclusions}

1. The possibility of producing the full-strength butt joint of sheet rolled titanium VT1-0 $12 \mathrm{~mm}$ thick, hardened by nitrogen (0.098 wt.\%) from the gas phase in the ASR process, using laser welding was shown.

2. The results of macro-, microexaminations, measurements of distribution of microhardness $H V$, evaluation of mechanical properties in the tests on static tension and impact bending (values of impact toughness $K C U_{+20}$ are almost at the same level for both cases, and bending angle for butt laser weld $2\left(\mathrm{He}+\mathrm{N}_{2}+\mathrm{Ar}\right)$ is almost 1.5 times larger than that for butt laser weld $1(\mathrm{He}+$ $+\mathrm{Ar}+\mathrm{Ar})$ ) confirm high quality and fullstrength of butt double-sided joint (homogeneity of its structure, absence of cracks, pores and other defects), and evidence of the challenging development of works on application of laser welding of commercial titanium VT1-0 ASR, hardened by nitrogen (up to $0.1 \mathrm{wt} \%$ ).

1. Gurevich, S.M., Zamkov, V.N., Blashchuk, V.E. et al. (1986) Metallurgy and technology of welding of titanium and its alloys. Kiev: Naukova Dumka.

2. Medovar, B.I., Saenko, V.Ya., Kumysh, V.I. et al. (1994) Hardening of titanium by nitrogen alloying from vapor phase during arc slag remelting. Problemy Spets. Elektrometallurgii, 3/4, 12-17.

3. Medovar, B.I., Saenko, V.Ya., Kumysh, V.I. et al. (1995) Properties of thick plates rolled from largetonnage slab ingot of VT1-0 titanium ASR of $4.5 \mathrm{t}$ mass. Ibid., 2, 10-14.

4. Medovar, B.I., Saenko, V.Ja., Grigorenko, G.M. et al. (1996) Arc-slag remelting of steel and alloys. Cambridge: Intern. Sci. Publ.

5. Saenko, V.Ya., Polishko, A.A., Ryabinin, V.A. et al. (2014) Electron beam welding of sheet commercial titanium VT1-0 hardened by nitrogen in the process of arc-slag remelting and properties of produced joints. The Paton Welding J., 11, 46-49.

6. Paton, B.E., Shelyagin, V.D., Akhonin, S.V. et al. (2009) Laser welding of titanium alloys. Ibid., 7, 30-34.

7. Shelyagin, V.D., Akhonin, S.V., Khaskin, V.Yu. et al. (2013) Hybrid welding of titanium alloys with Nd:YAG laser radiation and arc with nonconsumable electrode. In: Proc. of Int. Conf. on Laser Technologies in Welding and Materials Processing, 96-100. Kiev: IAW.

8. Krivtsun, I.V., Shelyagin, V.D., Bushma, A.N. et al. (2013) Ibid , 44-47.

9. Fellouz, J. (1982) Fractography and atlas of fractograms: Refer. Book. Moscow: Metallurgiya.

Received 11.02.2015 